\title{
Enteropathy-Associated T-Cell Lymphoma by Ann Arbor Stage
}

National Cancer Institute

\section{Source}

National Cancer Institute. Enteropathy-Associated T-Cell Lymphoma by Ann Arbor Stage. NCI Thesaurus. Code C141295.

An anatomic stage for enteropathy-associated T-cell lymphoma based on the Ann Arbor classification criteria. 